Article

\title{
Upstream Pricing Schemes, Trade Liberalization, Trade and Environmental Policies of Downstream Countries
}

\author{
Bo Li ${ }^{1}$ (D), Fei Xing ${ }^{2, *(1)}$ and Mark Yu ${ }^{3}$ \\ 1 School of Economics and Environmental Resources, Hubei University of Economics, 8 Yangqiaohu Avenue, \\ Wuhan 430205, China; libo@hbue.edu.cn \\ 2 School of Economics, Huazhong University of Science and Technology, 1037 Luoyu Road, \\ Wuhan 430074, China \\ 3 Department of Agriculture \& Consumer Science, Tarleton State University, 1333 W Washington Street, \\ Stephenville, TX 76401, USA; yu@tarleton.edu \\ * Correspondence: feixinghust@gmail.com; Tel.: +86-159-2745-9629
}

Received: 7 June 2018; Accepted: 6 July 2018; Published: 12 July 2018

\begin{abstract}
Trade liberalization has a significant impact on the environment and social welfare of countries. In the real world, almost all industries exist upstream and downstream firms but the existing literature on the impact of trade liberalization rarely discuss the interaction between upstream and downstream firms. The goal of this study is to analyze the effects of trade liberalization on the trade policies, environmental policies and social welfare of downstream exporting countries when different pricing schemes (uniform pricing vs. discriminatory pricing) are implemented by upstream monopoly firms. By constructing a three-stage dynamic game model we found that, regardless of pricing schemes, trade liberalization leads to increase both environmental taxes and import taxes. Trade liberalization increases the social welfare of downstream countries under discriminatory pricing, while trade liberalization first reduces and then increases the social welfare of downstream countries under uniform pricing. The results indicate that the downstream countries always have the incentive to participate in trade agreements that integrate markets when discriminatory pricing schemes will be implemented by upstream firms. This finding is the most significant contribution of this paper which has not been addressed in the previous literature.
\end{abstract}

Keywords: discriminatory pricing; uniform pricing; trade liberalization; trade policy; environmental policy

JEL Classification: F18; L13; Q56

\section{Introduction}

Trade liberalization has been considered an important proposition in the field of international trade by promoting the effective allocation of economic resources and improving the social welfare of all countries [1]. Therefore, many countries are seeking to sign bilateral or multilateral free trade agreements in the face of the difficult progress of the multilateral trade negotiations implemented within the WTO. Existing and pending free trade areas include NAFTA (The North American Free Trade Agreement is an agreement signed by Canada, Mexico and the United States, creating a trilateral trade bloc in North America. The agreement came into force on 1 January 1994), AFTA (The ASEAN Free Trade Area is a trade bloc agreement by the Association of Southeast Asian Nations supporting local manufacturing in all ASEAN countries. ASEAN now has ten members, namely, Brunei, Indonesia, Malaysia, Philippines, Singapore, Thailand, Vietnam, Laos, Myanmar 
and Cambodia), APT (ASEAN plus Three is a forum that functions as a coordinator of co-operation between the Association of Southeast Asian Nations and the three East Asia nations of China, Japan and South Korea), ECFA (The Economic Cooperation Framework Agreement is a preferential trade agreement between the governments of the People's Republic of China and Taiwan that aims to reduce tariffs and commercial barriers between the two sides. The pact, signed on 29 June 2010) and CEPA (The Comprehensive Economic Partnership Agreement is a free trade agreement between India and South Korea. The agreement was signed on 7 August 2009), among others. One of the common features of these free trade agreements is the reduction of mutual non-tariff trade costs through improving infrastructure and reducing bureaucratic barriers to trade and to serve as the major means of economic integration.

However, subject to the prevalence of trade liberalization, countries can use environmental policy in place of strategic trade policy, raising concerns among environmentalists that trade liberalization will lead to "ecological dumping" [2], which Rauscher [3] defined as the government attempted to subsidize manufacturers by implementing relatively loose environmental policies so that they can sell product to foreign markets at lower prices; or "ecological dumping" is exporting countries exchange export profits through sacrificing the environment. When all participating countries in the international market carry out ecological dumping through strategic environmental policies, the environmental quality of each country deteriorates together. Both the losses brought on by environmental pollution and the gains from resource allocation can cause changes in a country's social welfare. Hence, it is an important theoretical issue whether or not trade liberalization will lead to countries adopting "ecological dumping" and trade liberalization can promote social welfare.

While studying the impact of trade liberation and environmental policy, there are two types of research. Some research studied the related issues from an empirical perspective. Antweiler et al. [4] used data from more than 40 countries to estimate the environmental effects of trade and found that trade liberalization benefits the environment in general. Dean [5] used data from provinces in China and found that trade liberalization has reduced water pollution. Another type of research is to theoretically analyze the impact of trade liberalization on environmental policies and social welfare based on the framework of strategic environmental policies [1,6-12]. Walz and Wellisch [9] introduced environmental factors into the traditional trade model of export from two countries to a third country (hereafter labeled as "three-country two-factory" model). Burguet and Sempere [1] analyzed the impact of trade liberalization on each country's environmental policy as well as social welfare by using an imperfectly competitive two-country mutual dumping model. Fujiwara [11] introduced a Trans-boundary pollution model for studying the impacts of two different forms of trade liberalization (reduction in bilateral tariff barriers and reduction in bilateral trade costs) on social welfare and found that the impact of trade liberalization in either form on the social welfare is uncertain. Tanguay [10] compared the equilibrium results under the condition in which the government adopts both import tariffs and environmental taxes to the equilibrium results under the condition in which the government adopts only the environmental tax and found that trade liberalization lowered the environmental tax and worsened the social welfare. Although Tanguay [10] studied the endogenous mechanisms underlying both tariffs and environmental taxes, the study mainly explored trade liberalization in the form of a fall in tariff barriers, while some relevant empirical studies have shown that the decline in trade costs is an important form of trade liberalization [13]. Fujiwara [12] explored the endogenous decision mechanism of tariffs and environmental taxes in the bilateral competition model of imperfect competition and treated the decrease in exogenous trade costs as the process of trade liberalization to analyze the impact of trade liberalization on environmental taxes, import tariffs and social welfare. Results showed that the decline in trade costs can lead to lower environmental taxes but higher import tariffs and the impact of trade liberalization on social welfare depends on the coefficient of environmental damages.

The aforementioned studies all implicitly assumed that either there is no intermediate product market or the intermediate product market is perfectly competitive. In reality, the production of the 
final products of a downstream country always needs imported upstream input and the market for upstream intermediate products is often monopolistic [14]. For example, the steel industry in the vast majority of countries needs to import iron ore, which is controlled by the three largest miners (BHP Billiton, CVRD and Rio Tinto) in the world. These upstream monopoly firms can implement either uniform pricing or discriminatory pricing. The international iron ore market is divided into the Asian market and European market by the traditional long-term contract pricing mechanisms. Every fiscal year, the price of iron ore in the Asian market is determined by the monopoly alliance of three largest miners and Japanese buyers, while the iron ore price in European market is determined by the same monopoly alliance and German buyers. Therefore, an upstream intermediate product exporting country is introduced in this paper on the basis of Fujiwara [12] model to explore the effects of trade liberalization (decreases in non-tariff trade costs) on the trade policies, environmental policies and social welfare of the downstream exporting countries. In our model, there are two downstream exporting countries and each country has only one monopoly firm producing the final product and discharging pollution during the production process. In the upstream exporting country, there is one monopoly firm specializing in the production of intermediate products, which are exported separately to the two downstream countries. The two downstream countries dumped their final products to one another by choosing both import tariffs and environmental taxes.

Compared with the model in Fujiwara [12], the model in this paper expands in two aspects. First, we introduced an upstream intermediate product exporting country, which makes downstream exporting countries need to not only consider the horizontal strategic interactions between the two downstream exporting countries in the process of formulating the policies but also pay attention to the vertical strategic interactions between the upstream and downstream countries. On the other hand, this paper analyzed the effects of trade liberalization on the trade policy, environmental policy and social welfare of the downstream exporting countries when implementing different pricing schemes (uniform pricing and discriminatory pricing) by upstream monopoly firm.

Theoretically, when upstream firms have enough monopoly power, price discrimination can be used as a means of vertical control [15] so the policy competition and trade liberalization among downstream countries will inevitably be greatly affected by the price discrimination of intermediary products. However, the relevant literature on strategic environmental policy does not discuss this issue. Bernhofen [16] was the first to study the impact of different upstream pricing schemes (uniform pricing and discriminatory pricing) on the equilibrium trade policy of downstream exporters within the framework of a vertical correlation market. But the study did not discuss the implementation of environmental policies by the two downstream exporters attributable to fail to consider environmental factors. Also, the model did not consider the domestic consumption problems of the downstream countries. Instead, it assumed that the two downstream countries export the final product to other markets in the world. The objective of this paper is to consider the impact of trade liberalization on the trade and environment of downstream countries under different upstream pricing schemes, to extend the literature on strategic trade and environmental policies accordingly and to make up for the shortcomings of related theoretical studies.

We will use the model constructed in this paper to explore the following three issues: First, how does the strategic interaction between upstream and downstream countries affect the formulation of trade and environmental policies of downstream countries? Secondly, the implementation of different pricing schemes by upstream firms changes the way the upstream firms extract profits from downstream firms and thus affects the output of the final product. Will the social welfare of the downstream countries be affected by trade liberalization under the different pricing schemes and are there significant differences in changing trends under the different pricing schemes? Finally, since the decline in non-tariff trade costs can affect the social welfare in related countries, is there a motivation between downstream countries to reach a trade agreement on reducing non-tariff barriers?

The remaining contents of this paper are structured as follows: the second section introduces the basic assumptions of the model; the third discusses the equilibrium trade and environmental policies 
of two downstream exporting countries under uniform pricing and discriminatory pricing conditions; the fourth describes the impact of trade liberalization on trade and environmental policy; the fifth discusses the impact of market integration on the social welfare of downstream countries under these two different pricing schemes; and the last section is the conclusion.

\section{Model}

A country $M$ specializing in the production of upstream intermediate products is added into the traditional trade model of two-country mutual dumping $[1,12]$ and there is a monopoly firm in Country $M$. It is assumed that there are two downstream opponent Countries $H$ and $F$ producing the final product and each country has only one monopoly firm producing the final product, respectively. Country $H$ and Country $F$ produce substitute products and dump them to one another and the environment will be polluted during production process. Therefore, the governments can collect import tariffs on the final products and environmental taxes on the environmental pollution. In the process of reciprocal dumping, the final product manufacturers need to pay the non-tariff trade costs. Hence, the downstream firms pay not only internal environment tax but also the import tariffs and non-tariff trade costs when selling their products abroad. The downstream firms in Countries $H$ and $F$ purchase the intermediate products as inputs from the upstream monopoly firm in Country $M$, which can implement either uniform pricing or discriminatory pricing schemes when exporting the intermediate products.

The basic model is a three-stage dynamic game. In the first stage, the governments of two downstream Countries $H$ and $F$ formulate their import tariff $t_{i}$ and environmental tax $\tau_{i}$, wherein $i=h$ or $f$. In the second stage, the upstream monopoly firm determines the export price $w_{i}$. During the third stage, the two downstream firms dump their final products to the opponent country and engage in Cournot yield competition in both of the downstream countries.

Specifically, the output of final products manufactured by the two downstream firms are $Y_{i}$. Due to the intra-industry trade between two downstream countries, $y_{i}$ and $y_{i}^{*}$ represent the output manufactured by a downstream exporter and sold to its own country and opponent country, respectively, wherein $Y_{i}=y_{i}+y_{i}^{*}$. For the downstream firms, it is assumed that the linear market demand for the final products is $P_{i}=a-Q_{i}$, wherein $P_{i}$ is the price of final product in Country $i, Q_{i}$ is the market demand in Country $i$, satisfying the conditions that $Q_{i}=y_{i}+y_{j}^{*}, i, j=h, f$ and $i \neq j$ and $a$ is spontaneous demand which is large enough to ensure the significance of the corresponding variables. Pollutants are emitted during the production process and the emission capacity $e_{i}$ satisfying the condition of $e_{i}=\theta Y_{i}$, where $\theta$ represents the emission coefficient. This study assumes $\theta=1$, that one unit of emitted pollutants is produced in the process of producing each unit of the final product. For the convenience of analysis, the study also assumes that the production cost of each unit of final product is zero (0). For the upstream firm in Country $M, x_{h}$ and $x_{f}$ represent the amount of intermediate product sold to Country $H$ and Country $F$, respectively, of which the marginal cost is represented by $c$.

The policies implemented by governments of downstream exporters aim to maximize their own countries' social welfare, including consumer welfare, profits of firms, income from import tariffs, environmental taxes and also accounting for environmental damage. In line with Tanguay [10] and Fujiwara [12], this study assumes that environmental damage cost is a linear function in the form of $d e_{i}$, in which $d$ indicates the environmental damage coefficient and that per unit export of final products pays the non-tariff trade costs $T$, including transportation costs, stamp costs and all trade procedures, decreases in the process of trade liberalization. Backward Induction is used to solve the model below. 


\section{The Equilibrium of Trade and Environmental Policies}

\subsection{Discriminatory Pricing Scheme}

In the third stage of the game, given the trade and environmental policies of the two downstream countries $\left(t_{i}\right.$ and $\left.\tau_{i}\right)$ and the prices of upstream intermediate products $\left(w_{i}\right)$, the two downstream firms provide final products to these two countries (Country $H$ and $F$ ) and engage in Cournot yield competition in the market. The profit function of this two firms is:

$$
\begin{gathered}
\pi_{i}=\left(P_{i}-w_{i}-\tau_{i}\right) y_{i}+\left(P_{j}-w_{i}-\tau_{i}-t_{j}-T\right) y_{i}^{*} \\
=\left(a-y_{i}-y_{j}^{*}-w_{i}-\tau_{i}\right) y_{i}+\left(a-y_{j}-y_{i}^{*}-w_{i}-\tau_{i}-t_{j}-T\right) y_{i}^{*}
\end{gathered}
$$

As the downstream firms seek to maximize profits, taking the first-order conditions from Equation (1) and solving, the equilibrium outputs of the final products are:

$$
\begin{aligned}
& y_{i}=\frac{a-2\left(w_{i}+\tau_{i}\right)+\left(w_{j}+\tau_{j}+t_{i}+T\right)}{3} \\
& y_{i}^{*}=\frac{a+w_{j}+\tau_{j}-2\left(w_{i}+\tau_{i}+t_{j}+T\right)}{3}
\end{aligned}
$$

If discriminatory pricing scheme is implemented, the upstream monopoly firm will separately price the intermediate products in the two downstream firms during the second stage of the game. Given the import tariff and environmental tax on downstream countries, the profit made by the upstream firm $\left(\pi^{M}\right)$ is the difference between the sales income from intermediate product and production costs:

$$
\pi^{M}=\left(w_{h}-c\right) x_{h}+\left(w_{f}-c\right) x_{f}
$$

Note that the production of one unit of final product needs one unit of intermediate product. Thus, the derived demand for the intermediate product can be shown to be as follows, by combining Equations (2) and (3):

$$
x_{i}=y_{i}+y_{i}^{*}=\frac{2 a-4 w_{i}+2 w_{j}-4 \tau_{i}+2 \tau_{j}+t_{i}-2 t_{j}-T}{3}
$$

Substituting Equation (5) into Equation (4), the sale price of upstream products under discriminatory pricing will be as follows, by first-order condition for maximizing profits of upstream firm.

$$
w_{i}=\frac{a+c}{2}-\frac{2 \tau_{i}+t_{j}+T}{4}
$$

Substituting Equation (6) into Equations (2) and (3), the outputs of final products will be as follows:

$$
\begin{aligned}
& y_{i}=\frac{2 a-2 c-4 \tau_{i}+2 \tau_{j}+3 t_{i}+2 t_{j}+5 T}{12} \\
& y_{i}^{*}=\frac{2 a-2 c-4 \tau_{i}+2 \tau_{j}-t_{i}-6 t_{j}-7 T}{12}
\end{aligned}
$$

According to the final products' market demand function, it can be found that the consumer surplus is $C S_{i}=Q_{i}^{2} / 2=\left(y_{i}+y_{j}^{*}\right)^{2} / 2$, the profit of downstream firms is $\pi_{i}=y_{i}^{2}+y_{i}^{* 2}$, the environmental tax imposed by domestic government is $\tau_{i}\left(y_{i}+y_{i}^{*}\right)$, the import tariff is $t_{i} y_{j}^{*}$ and the environmental damage is $d\left(y_{i}+y_{i}^{*}\right)$. Hence, the social welfare function of downstream countries will be as follows:

$$
W_{i}=C S_{i}+\pi_{i}+\tau_{i}\left(y_{i}+y_{i}^{*}\right)+t_{i} y_{j}^{*}-d\left(y_{i}+y_{i}^{*}\right)
$$


As downstream countries seek to maximize their own social welfare by developing the optimal trade and environmental policies, the equilibrium environmental tax and tariff obtained from the first-order conditions are:

$$
\begin{aligned}
\tau_{i}^{D} & =\frac{26 a-26 c+202 d-23 T}{228} \\
t_{i}^{D} & =\frac{22 a-22 c-22 d-37 T}{114}
\end{aligned}
$$

where, $\tau_{i}^{D}$ and $t_{i}^{D}$ indicate the equilibrium environmental tax and import tariff under discriminatory pricing.

\subsection{Uniform Pricing Scheme}

In the third stage of the game, the two downstream firms engage in Cournot yield competition in their final products market. Unlike in discriminatory pricing schemes which the prices of upstream intermediate products are both $w$, the equilibrium outputs of final products under uniform price scheme are as follows:

$$
\begin{aligned}
& y_{i}=\frac{a-w-2 \tau_{i}+\left(\tau_{j}+t_{i}+T\right)}{3} \\
& y_{i}^{*}=\frac{a-w+\tau_{j}-2\left(\tau_{i}+t_{j}+T\right)}{3}
\end{aligned}
$$

If a uniform pricing scheme is implemented, profit function of the upstream monopoly firm will be as follows in the second stage of the game:

$$
\pi^{M}=(w-c) x_{h}+(w-c) x_{f}
$$

By substituting Equations (12) and (13) into Equation (14), the sales price of upstream products will be as follows by the first-order condition for maximizing profits of upstream firm.

$$
w=\frac{4(a+c)-2\left(\tau_{i}+\tau_{j}+T\right)-\left(t_{i}+t_{j}\right)}{8}
$$

Similarly, the output of final products will be as follows by substituting the Equation (15) into Equations (12) and (13):

$$
\begin{aligned}
y_{i} & =\frac{4 a-4 c-18 \tau_{i}+6 \tau_{j}+7 t_{i}-t_{j}+6 T}{24} \\
y_{i}^{*} & =\frac{4 a-4 c-18 \tau_{i}+6 \tau_{j}-t_{i}-17 t_{j}-18 T}{24}
\end{aligned}
$$

Under the uniform pricing scheme, the results are similar to discriminatory pricing scheme, the consumer surplus is $C S_{i}=Q_{i}^{2} / 2=\left(y_{i}+y_{j}^{*}\right)^{2} / 2$ and the environmental tax imposed by domestic government is $\tau_{i}\left(y_{i}+y_{i}^{*}\right)$, the import tariff is $t_{i} y_{j}^{*}$ and the environmental damage is $d\left(y_{i}+y_{i}^{*}\right)$. However, the profit is different for downstream firms $\left(\pi_{i} \neq y_{i}^{2}+y_{i}^{* 2}\right)$, which can be expressed as follows:

$$
\begin{aligned}
& \pi_{i}=\left(p_{i}-w-\tau_{i}\right) y_{i}+\left(p_{j}-w-\tau_{i}-t_{j}-T\right) y_{i}^{*} \\
& =\frac{4 a-4 c-6 \tau_{i}+18 \tau_{j}+13 t_{i}+5 t_{j}+18 T}{24} \cdot \frac{4 a-4 c-18 \tau_{i}+6 \tau_{j}+7 t_{i}-t_{j}+6 T}{24} \\
& +\frac{4 a-4 c-6 \tau_{i}+18 \tau_{j}+5 t_{i}-11 t_{j}-6 T}{24} \cdot \frac{4 a-4 c-18 \tau_{i}+6 \tau_{j}-t_{i}-17 t_{j}-18 T}{24}
\end{aligned}
$$

The social welfare function of downstream countries is as follows:

$$
W_{i}=C S_{i}+\pi_{i}+\tau_{i}\left(y_{i}+y_{i}^{*}\right)+t_{i} y_{j}^{*}-d\left(y_{i}+y_{i}^{*}\right)
$$


As downstream countries seek to maximize their own social welfare by developing the optimal trade and environmental policies, the equilibrium environmental tax and tariff will be as follows by the first-order condition:

$$
\begin{aligned}
\tau_{i}^{U} & =\frac{-32 a+32 c+234 d-63 T}{372} \\
t_{i}^{U} & =\frac{12 a-12 c-18 d-19 T}{62}
\end{aligned}
$$

where, $\tau_{i}^{U}$ and $t_{i}^{U}$ indicate the equilibrium environmental tax and import tariff under uniform pricing, respectively.

\section{Impact of Trade Liberalization on Trade and Environmental Policies}

\subsection{Discriminatory Pricing Scheme}

Taking the derivative of trade costs $T$ with equilibrium trade and environmental policies in Equations (10) and (11):

$$
\frac{\partial \tau_{i}^{D}}{\partial T}=-\frac{23}{228}<0, \frac{\partial t_{i}^{D}}{\partial T}=-\frac{37}{114}<0
$$

The following proposition can be concluded from the results above.

Proposition 1. When the discriminatory pricing scheme is implemented by upstream firm, the trade liberalization (with non-tariff trade costs) would increase the equilibrium environmental taxes and import tariffs of the two downstream countries.

In order to further understand the economic meaning of Proposition 1, the social welfare functions of downstream countries are decomposed as follows:

$$
\begin{aligned}
& W_{i}=C S_{i}+\pi_{i}+\tau_{i} Y_{i}+t_{i} y_{j}^{*}-d Y_{i}=a\left(y_{i}+y_{j}^{*}\right)-\frac{\left(y_{i}+y_{j}^{*}\right)^{2}}{2}-P_{i}\left(y_{i}+y_{j}^{*}\right) \\
& +\left(P_{i}-w_{i}-\tau_{i}\right) y_{i}+\left(P_{i}-w_{i}-\tau_{i}-t_{j}-T\right) y_{i}^{*}+\tau_{i}\left(y_{i}+y_{i}^{*}\right)+t_{i} y_{j}^{*}-d\left(y_{i}+y_{i}^{*}\right) \\
& =\underbrace{\left(y_{i}+y_{j}^{*}\right)\left(2 a-y_{i}-y_{j}^{*}\right) / 2}_{H S}+\underbrace{\left(P_{j}-t_{j}-T\right) y_{i}^{*}-\left(P_{i}-t_{i}\right) y_{j}^{*}}_{V S}-\underbrace{w_{i}\left(y_{i}+y_{i}^{*}\right)}_{D}-\underbrace{d\left(y_{i}+y_{i}^{*}\right)}_{D S}
\end{aligned}
$$

where, $U$ indicates consumer utility; $H S$ indicates the horizontal net trade surplus between the two downstream firms; VS indicates the vertical net trade surplus between the upstream and downstream countries; and $D$ indicates the environmental damage. Taking the partial derivative of environmental tax $(\tau)$ and import tariff $(t)$ with respect to $U, H S, V S$ and $D$, respectively, the results are:

$$
\frac{\partial U_{i}}{\partial \tau_{i}}<0, \frac{\partial V S_{i}}{\partial \tau_{i}}>0, \frac{\partial H S_{i}}{\partial \tau_{i}}<0, \frac{\partial D_{i}}{\partial \tau_{i}}<0, \frac{\partial U_{i}}{\partial t_{i}}<0, \frac{\partial V S_{i}}{\partial t_{i}}<0, \frac{\partial H S_{i}}{\partial t_{i}}>0, \frac{\partial D_{i}}{\partial t_{i}}>0
$$

As shown in Equation (24), the following four results about the downstream countries can be found:

(a) The oligopolistic market structure would lead to the shortages in domestic products in downstream countries. And the decrease in environmental taxes and import tariffs in one country could boost consumer utility by increasing the supply of products in the domestic market.

(b) The decrease in environmental tax of a downstream country could expand its domestic output and increase its horizontal net trade surplus which means that more profit would be made from the opponent country. And the increase in import tariffs of a downstream country could reduce the imports from the opponent country, thus increasing its horizontal net trade surplus.

(c) The decrease in environmental taxes of a downstream country could expand its domestic output and increase the induced demand for intermediate products, which means that the upstream 
firm could extract more profits by raising the price of intermediate products, thus lowering the vertical net trade surplus of the downstream country. The increase in import tariffs would have the same effect.

(d) The increase in import tariffs of a downstream country would exacerbate environmental damage. And the decrease in environmental tax would have the same effect.

Based on the results above, the corresponding influences of decreases in trade costs could be further analyzed. Taking the partial derivatives with respect to $T$ in the Equation (24),

$$
\begin{gathered}
\frac{\partial^{2} U_{i}}{\partial \tau_{i} \partial T}=-\frac{1}{36}<0, \frac{\partial^{2} U_{i}}{\partial t_{i} \partial T}=-\frac{1}{24}<0 \\
\frac{\partial^{2} H S_{i}}{\partial \tau_{i} \partial T}=\frac{1}{4}>0, \frac{\partial^{2} H S_{i}}{\partial t_{i} \partial T}=-\frac{17}{72}<0 \\
\frac{\partial^{2} V S_{i}}{\partial \tau_{i} \partial T}=-\frac{1}{4}<0, \frac{\partial^{2} V S_{i}}{\partial t_{i} \partial T}=\frac{1}{24}>0 \\
\frac{\partial^{2} D_{i}}{\partial \tau_{i} \partial T}=\frac{\partial^{2} D_{i}}{\partial t_{i} \partial T}=0
\end{gathered}
$$

As shown by Equation (25), the lower the trade cost, the fiercer the product competition is between the two downstream countries and the less distortion would be caused by the oligopolistic market structure, while the effect of reducing environmental tax or import tariffs on the utility of consumers will be lessened. As shown by Equation (26), the lower the trade cost, the easier for the two downstream countries to generate more profit from one another by expanding export. Hence, the downstream countries would be more motivated to reduce environmental taxes or raise import tariffs. As shown in Equation (27), the lower the trade cost, the higher the degree of market integration between the two downstream countries and the greater the incentives for the downstream firms to extract profits from the upstream firm (or to increase the vertical net trade surplus) by raising the domestic environmental tax or reducing the import tariff. As shown in Equation (28), changes in the trade costs have no effect on the motivation of downstream countries to impose environmental taxes or import tariffs for the transfer of pollution.

Based on Equations (25)-(28), the following two conclusions can be obtained.

(a) Since $\frac{\partial^{2} H S_{i}}{\partial \tau_{i} \partial T}=\frac{1}{4}$ and $\frac{\partial^{2} V S_{i}}{\partial \tau_{i} \partial T}=-\frac{1}{4}$, decreases in trade costs have offsetting effects on the motivation of downstream countries to raise the horizontal net trade surplus by lowering the environmental taxes and the motivation to increase the vertical net trade surplus by raising environmental taxes. Hence, the impact of trade liberalization on the equilibrium environmental policy is obtained as $\frac{\partial^{2} U_{i}}{\partial \tau_{i} \partial T}=-\frac{1}{36}$. Subject to the decrease in trade costs $T$, the downstream countries increase the equilibrium environmental tax, because the decline in trade costs has promoted competition among downstream firms and the insufficiency of final products in their domestic market is less serious. In the end, the governments are not motivated to reduce environmental taxes.

(b) Since $\frac{\partial^{2} U_{i}}{\partial t_{i} \partial T}=-\frac{1}{24}$ and $\frac{\partial^{2} V S_{i}}{\partial t_{i} \partial T}=\frac{1}{24}$, the decreases in trade costs have offsetting effects on the motivation of downstream countries to increase the consumer utility by lowering the environmental taxes and the motivation to increase the vertical net trade surplus by raising environmental taxes. Hence, the impact of trade liberalization on the equilibrium import tariff is obtained as $\frac{\partial^{2} H S_{i}}{\partial t_{j} \partial T}=-\frac{17}{72}$. Subject to the decrease in trade costs $T$, the downstream countries increase the equilibrium import tariff. This is because the decline in trade costs has made it easier for downstream firms to extract profits from opponent country by expanding exports, whereas increasing import tariffs in a downstream country could inhibit the infusion of final products from the opponent country. Therefore, the governments have enough incentives to increase the horizontal net trade surplus by raising import tariffs. 


\subsection{Uniform Pricing Scheme}

Taking the derivatives of equilibrium trade and environmental policies in Equations (20) and (21) with respect to trade costs $T$ :

$$
\frac{\partial \tau_{i}^{U}}{\partial T}=-\frac{21}{124}<0, \frac{\partial t_{i}^{U}}{\partial T}=-\frac{19}{62}<0
$$

The following proposition can be concluded form the results given above:

Proposition 2. When the uniform pricing scheme is implemented by the upstream firm, the trade liberalization would also increase the equilibrium environmental taxes and import tariffs of the two downstream countries.

As suggested by comparing Propositions 1 and 2, the impact direction of trade liberalization on trade and environmental policies does not vary with the pricing schemes implemented by the upstream firm. In order to further understand the mechanism underlying Proposition 2, we take the partial derivatives of $U, H S, V S$ and $D$, with respect to environmental tax $(\tau)$ and import tariff $(t)$ :

$$
\begin{aligned}
& \frac{\partial U_{i}}{\partial \tau_{i}}<0, \frac{\partial V S_{i}}{\partial \tau_{i}}>0, \frac{\partial H S_{i}}{\partial \tau_{i}}<0, \frac{\partial D_{i}}{\partial \tau_{i}}<0, \\
& \frac{\partial U_{i}}{\partial t_{i}}<0, \frac{\partial V S_{i}}{\partial t_{i}}<0, \frac{\partial H S_{i}}{\partial t_{i}}>0, \frac{\partial D_{i}}{\partial t_{i}}>0
\end{aligned}
$$

To further analyze the influences of decreasing in trade costs, we take the second derivatives with respect to $T$ and $\tau_{i}$ in the above equations and obtain:

$$
\begin{gathered}
\frac{\partial^{2} U_{i}}{\partial \tau_{i} \partial T}=-\frac{1}{4}<0, \frac{\partial^{2} U_{i}}{\partial t_{i} \partial T}=-\frac{5}{36}<0 \\
\frac{\partial^{2} H S_{i}}{\partial \tau_{i} \partial T}=\frac{1}{4}>0, \frac{\partial^{2} H S_{i}}{\partial t_{i} \partial T}=-\frac{1}{8}<0 \\
\frac{\partial^{2} V S_{i}}{\partial \tau_{i} \partial T}=-\frac{1}{2}<0, \frac{\partial^{2} V S_{i}}{\partial t_{i} \partial T}=0 \\
\frac{\partial^{2} D_{i}}{\partial \tau_{i} \partial T}=\frac{\partial^{2} D_{i}}{\partial t_{i} \partial T}=0
\end{gathered}
$$

Equations (31), (32) and (34) indicate similar conclusions to those of Equations (25), (26) and (28): (a) The lower the cost of trade, the lesser the effect of reducing environmental taxes or import tariffs on consumer utility is. (b) The lower the trade cost, the easier for the two downstream firms to extract profits from one another by expanding exports and the downstream countries would be more motivated to reduce environmental taxes or raise import tariffs. And (c) the changes in the trade costs have no effect on the motivation of downstream countries to impose environmental taxes or import tariffs for the transfer of pollution.

Equation (33) shows that, lowering the trade cost will increase the motivation of the downstream countries to extract profits from the upstream firm (to increase the vertical net trade surplus) by raising the domestic environmental tax, which has the same impact as it did under the discriminatory pricing scheme in Equation (23). The difference lies in that, under the uniform pricing scheme, the decrease in trade costs has no effect on the motivation of downstream countries to extract profits from the upstream firm (to increase the vertical net trade surplus) by reducing import tariffs. This difference is caused by the "Spillover Effect" of changes in policy under uniform pricing scheme. When a downstream country promotes output and export of the opponent downstream country through lower import tariffs, the increase in demand for intermediate products by the opponent country will 
raise the uniform price determined by upstream firm. Eventually, the upstream firm would extract more profit from downstream firms.

With respect to the impact of decreasing in trade costs on environmental taxes, Equations (31)-(34) show that $\frac{\partial^{2} U_{i}}{\partial \tau_{i} \partial T}=-\frac{1}{4}$ and $\frac{\partial^{2} H S_{i}}{\partial \tau_{i} \partial T}=\frac{1}{4}$, which means that the decrease in trade costs has offsetting effects on the motivation of downstream countries to raise the horizontal net trade surplus by lowering the environmental taxes and the motivation to increase the consumer utility by raising environmental taxes. Hence, the impact of trade liberalization on the equilibrium environmental policy is determined by $\frac{\partial^{2} V S_{i}}{\partial \tau_{i} \partial T}=-\frac{1}{2}$. Subject to the decrease in trade costs $T$, the downstream countries would increase the equilibrium environmental taxes. This is because the decline in trade costs has promoted competition among downstream firms and the government has been motivated to raise environmental taxes to increase the vertical net trade surplus by reducing domestic demand for intermediate products.

With respect to the impact of decreasing in trade costs on import tariffs, Equations (31)-(34) show that, since $\frac{\partial^{2} V S_{i}}{\partial t_{i} \partial T}=0$ and $\frac{\partial^{2} D_{i}}{\partial t_{i} \partial T}=0$, the impact of trade liberalization on equilibrium environmental policy is determined by the comprehensive influence of $\frac{\partial^{2} U_{i}}{\partial t_{i} \partial T}=-\frac{5}{36}$ and $\frac{\partial^{2} H S_{i}}{\partial t_{i} \partial T}=-\frac{1}{8}$. Subject to the decrease in trade costs, the downstream countries have the incentive to raise import tariffs due to the gradual correction of imperfect market and also have the motivation to reduce import tariff in order to obtain a higher level of vertical net trade surplus but the former surpasses the latter. Therefore, the downstream countries would increase import tariffs subject to the decrease in trade costs $(T)$.

\section{Impact of Trade Liberalization on the Social Welfare}

\subsection{Uniform Pricing Scheme}

By setting $y_{i}^{*}=0$, the maximum trade cost is as follows:

$$
\bar{T}=\frac{2}{27}(2 a-2 c-3 d)
$$

Substituting the equilibrium trade and environmental policies in Equations (20) and (21) into the social welfare function:

$$
\bar{W}(T)=\frac{377}{2883}\left(a^{2}+c^{2}+\frac{9}{2} d^{2}-2 a c-3 a d+3 c d\right)-\frac{112}{961}(2 a-2 c-3 d) T+\frac{9461}{7688} T^{2}
$$

Taking the first and second derivatives of Equation (36):

$$
\bar{W}^{\prime}(T)=-\frac{112}{961}(2 a-2 c-3 d)+\frac{9461}{3844} T, \bar{W}^{\prime \prime}(T)=\frac{9461}{3844}>0
$$

Substituting $T=0$ and $T=\bar{T}$ into Equations (36) and (37):

$$
W(T=0)>W(T=\bar{T}) \text { and } \bar{W}^{\prime}(0)<0, \bar{W}^{\prime}(\bar{T})<0
$$

The following proposition can be concluded from the above calculation:

Proposition 3. Under the uniform pricing scheme, the social welfare function of downstream countries is a convex function of trade costs. Trade liberalization first reduces and then increases the social welfare of downstream countries and $W(T=0)>W(T=\bar{T})$.

Lahiri and Ono [17] considered that the reduction in trade costs has two effects, of which one will improve consumer surplus through promoting the increase of final products output, while the other will reduce producer surplus due to the shift of production share to high-cost firms. When the trade cost is higher than a certain value, the decrease of producer surplus surpasses the increase of consumer surplus as the reduction of trade costs. When the trade cost is lower than a certain value, 
the increase in consumer surplus outweighs the decrease in producer surplus as the reduction of trade costs. Therefore, social welfare first decreases and then increases with the reduction of trade costs. Certainly, as a result of the uniform pricing scheme implemented by upstream firm, the profit made from downstream firms will be raised as the output of the final product increasing, which will partially offset the increase of social welfare brought by the expansion of the final product.

In addition, the social welfare of downstream countries would be affected by transportation costs and pollution costs as trade costs decreasing and final product output increasing. Among them, the impact of falling trade costs on environmental damage (pollution costs) is linear, while the decrease in trade cost leads first to an increase and then a decrease in the transportation cost of downstream countries. Correspondingly, the impact on social welfare is initially reduced and subsequently increased

Combined with the above analysis, the impact of the reduction of trade costs on the social welfare of the downstream countries is decreasing first and followed by increasing.

\subsection{Discriminatory Pricing Scheme}

Setting $y_{i}^{*}=0$, the maximum trade cost is as follows:

$$
\bar{T}=\frac{4}{43}(a-c-d)
$$

Similarly, substituting the equilibrium trade and environmental policies in Equations (10) and (11) into the social welfare function, we have:

$$
\bar{W}(T)=\frac{14182}{1083}\left(a^{2}+c^{2}+d^{2}-2 a c-2 a d+2 c d\right)-\frac{2377}{2166}(a-c-d) T+\frac{13879}{3249} T^{2}
$$

Taking the first and second-order derivatives of Equation (40) we obtain:

$$
\bar{W}^{\prime}(T)=-\frac{2377}{2166}(a-c-d)+\frac{27758}{3249} T, \bar{W}^{\prime \prime}(T)=\frac{27758}{3249}>0
$$

Substituting $T=0$ and $T=\bar{T}$ into Equations (40) and (41):

$$
W(T=0)>W(T=\bar{T}) \text { and } \bar{W}^{\prime}(0)<0, \bar{W}^{\prime}(\bar{T})<0
$$

The following proposition follows from the foregoing derivations.

Proposition 4. Under the discriminatory pricing scheme, the social welfare function of downstream countries is a convex function of trade costs. Trade liberalization always raises the social welfare of downstream countries and $W(T=0)>W(T=\bar{T})$.

Unlike Proposition 3, $\bar{W}^{\prime}(0)<0, \bar{W}^{\prime}(T)<0$ and the reduction in the cost of trade always increases the social welfare of downstream countries. According to the conclusion of Lahiri and Ono [17], under the uniform pricing scheme, when the cost difference between downstream firms is large (that is the trade cost is higher than a certain value), the decrease in producer surplus surpasses the increase in consumer surplus as the reduction of trade costs. And when the cost difference between downstream firms is small (that is the trade cost is lower than a certain value), the increase in consumer surplus outweighs the decrease in producer surplus as the reduction of trade costs. When a discriminatory pricing scheme is implemented, the upstream firm cross-subsidizes the two downstream firms by claiming high prices from low-cost firms [15], which partially offsets the cost difference between the upstream firms, so that the final effect is equivalent to that of "trade costs below a certain value." Therefore, with the reduction of trade costs, the increase in consumer surplus surpasses the decrease in producer surplus and the social welfare of downstream countries increases. 
Finally, by combining Proposition 3 and Proposition 4, we arrive at the follow corollary.

Corollary 1. Under the discriminatory pricing scheme, there are always incentives for the two downstream countries to reach a trade agreement on reducing the bilateral trade costs. Under the uniform pricing scheme, two downstream countries do not always have the incentive to reduce the bilateral non-tariff barriers.

According to Proposition 4, under discriminatory pricing, trade liberalization could always increase the social welfare of the downstream countries. Therefore, the downstream countries will always have the willingness to reach a trade agreement and to reduce bilateral non-tariff barriers. According to Proposition 3, under the unified pricing scheme, trade liberalization is likely to undermine the social welfare of downstream countries. Hence, downstream countries do not always have the incentive to reduce bilateral non-tariff barriers.

\section{Conclusions}

As an extension to the model proposed by Fujiwara [12], this study introduced an upstream intermediate product exporter and found that regardless of the kind of pricing schemes implemented by the upstream firm, trade liberalization (or a decline in non-tariff trade costs) would increase the environmental taxes and import tariffs imposed by the downstream countries. But its effects on social welfare differ under different pricing schemes. Under discriminatory pricing, the social welfare function is a convex function of trade costs and trade liberalization always improves social welfare in downstream countries. Under uniform pricing, the social welfare function is also a convex function of trade costs but the impact of trade liberalization on social welfare is uncertain.

The results also indicate that the downstream countries are always motivated to participate in trade dialogues and agreements aiming at market integration under a discriminatory pricing scheme. However, the downstream countries may not be willing to participate in bilateral trade liberalization under a uniform pricing scheme. This result has only appeared in the literature [1,9] in other forms of trade liberalization (e.g., a decline in import tariffs or a decrease in export subsidies but not a decline in non-tariff barriers). However, the existing literature in the form of trade liberalization with a decline in non-tariff barriers has not reached this same conclusion [11,12].

Although the main purpose of this paper is to expand the theoretical model of strategic environmental policy, this paper can still provide some inspirations for future empirical research. There are not many empirical studies based on strategic trade and environmental policies. Bernhofen [18] used data from petrochemical industries in the US and German to empirically analyze the factors affecting the level of intra-industry trade based on strategic trade theory. Friberg and Ganslandt [19] used data from the bottled water industry in Switzerland and found that prohibiting bilateral intra-industry trade would not improve social welfare. Future empirical studies can not only consider environmental factors on their basis to test the impact of trade liberalization on social welfare including environmental benefits but also can use upstream pricing schemes as a moderator to investigate the moderating effect of the upstream pricing schemes on the impact of trade liberalization.

Finally, due to the complexity and solvability of the model, this study assumes that both the demand function for final products and the pollution damage function are linear, the impacts of changes in such assumptions deserves further study. In addition, the mechanism of influence that this paper focuses on should also exist in future research. Finally, since this paper considers the linear pricing strategy alone, nonlinear pricing strategies will need to be discussed in a subsequent study.

Author Contributions: Conceptualization, F.X. and B.L.; Formal analysis, B.L., F.X. and M.Y.; Funding acquisition, F.X. and B.L.; Methodology, F.X.; Writing-review \& editing, B.L. and M.Y.

Acknowledgments: This research is supported by National Natural Science Foundation of China, under Grant: 71403093; National Social Science Foundation of China, under Grant: 16BGL125; and State Scholarship Fund of the China Scholarship Council, under Grant: 201708420044.

Conflicts of Interest: The authors declare no conflicts of interest. 


\section{References}

1. Burguet, R.; Sempere, J. Trade liberalization, environmental policy and welfare. J. Environ. Econ. Manag. 2003, 46, 25-37. [CrossRef]

2. Copeland, B.R.; Taylor, M.S. Trade, growth and the environment. J. Econ. Lit. 2004, 42, 7-71. [CrossRef]

3. Rauscher, M. On ecological dumping. Oxf. Econ. Pap. 1994, 46, 822-840. Available online: https: / /www.jstor. org/stable/2663501 (accessed on 6 June 2018). [CrossRef]

4. Antweiler, W.; Copeland, B.R.; Taylor, M.S. Is free trade good for the environment? Am. Econ. Rev. 2001, 91, 877-908. [CrossRef]

5. Dean, J.M. Does trade liberalization harm the environment? A new test. Can. J. Econ. 2002, 35, 819-842. [CrossRef]

6. Brander, J.A. Intra-industry trade in identical commodities. J. Int. Econ. 1981, 11, 1-14. [CrossRef]

7. Brander, J.; Krugman, P.A. 'Reciprocal Dumping' model of international trade. J. Int. Econ. 1983, 15, 313-321. [CrossRef]

8. Barrett, S. Strategic environmental policy and international trade. J. Public Econ. 1994, 54, 325-338. [CrossRef]

9. Walz, U.; Wellisch, D. Is free trade in the interest of exporting countries when there is ecological dumping. J. Public Econ. 1997, 66, 275-291. [CrossRef]

10. Tanguay, G.A. Strategic environmental policies under international duopolistic competition. Int. Tax Public Financ. 2001, 8, 793-811. [CrossRef]

11. Fujiwara, K. Strategic environmental policy and the gains from trade liberalization. Rev. Dev. Econ. 2010, 14, 360-373. [CrossRef]

12. Fujiwara, K. Market integration and competition in environmental and trade policies. Environ. Resour. Econ. 2011, 49, 561-572. [CrossRef]

13. Baier, S.L.; Bergstrand, J.H. The growth of world trade: Tariff, transport costs and income similarity. J. Int. Econ. 2001, 53, 1-27. [CrossRef]

14. Sanyal, K.K.; Jones, R.W. The theory of trade in middle products. Am. Econ. Rev. 1982, 72, 16-31. Available online: https:/ / www.jstor.org/stable/1808572 (accessed on 6 June 2018).

15. DeGraba, P. Input market price discrimination and the choice of technology. Am. Econ. Rev. 1990, 80, 1246-1253. Available online: http:/ / www.jstor.org/stable/2006774 (accessed on 6 June 2018).

16. Bernhofen, D.M. Strategic trade policy in a vertically related industry. Rev. Int. Econ. 1997, 5, 429-433. [CrossRef]

17. Lahiri, S.; Ono, Y. Foreign direct investment, local content requirement and profit taxation. Econ. J. 1998, 108, 444-457. [CrossRef]

18. Bernhofen, D.M. Intra-industry trade and strategic interaction: Theory and evidence. J. Int. Econ. 1999, 47, 225-244. [CrossRef]

19. Friberg, R.; Ganslandt, M. An empirical assessment of the welfare effects of reciprocal dumping. J. Int. Econ. 2006, 70, 1-24. [CrossRef]

(C) 2018 by the authors. Licensee MDPI, Basel, Switzerland. This article is an open access article distributed under the terms and conditions of the Creative Commons Attribution (CC BY) license (http://creativecommons.org/licenses/by/4.0/). 